\title{
CHECKING THE LOW TRACK LATTICE GIRDER BRIDGES FOR ROBUSTNESS
}

Carmen Bucur- Professor, PhD, Eng. - Technical University of Civil Engineering, Bucharest, Romania, e-mail bucurmecanica@yahoo.com

\section{Rezumat}

Când spui despre un lucru sau o ființă că sunt robuste îți imaginezi o entitate completă din punct de vedere al elementelor ce se presupune că o compun și care emană forță și siguranță. Noțiunea de robustețe este asociată multor domenii de activitate. Ca atare există multe definiții care individualizează noțiunea de robustețe în funcție de domeniul de studiu.

Lucrarea îşi propune să se alăture studiilor actuale cu o nouă cercetare în domeniul podurilor. Obiectul studiului îl reprezintă trei structuri de tip grinzi cu zăbrele metalice cale jos pentru cale ferată.

Articolul cuprinde şi o scurtă prezentare a modului în care noţiunea de robusteţe structurală se regăseşte în normele naţionale.

Cuvinte cheie: robustețe, standarde, pod, grinzi cu zăbrele metalice

\section{Abstract}

When you say about a thing or a being that they are robust, you imagine a complete entity from the point of view of its component parts giving out force and safety. The notion of robustness is associated with a lot of activity domains. Consequently, there are many definitions individualizing the robustness notion depending on the study domain.

The work aims to join in the present day studies with a new research in the bridge domain. The object of the study is represented by three low track steel lattice girder railway bridges.

In the article there is also presented the way the structural robustness notion is to be found in the national codes.

Keywords: robustness, technical regulations, bridge, steel lattice girder

\section{INTRODUCTION}

When you say about a thing or a being that they are robust, you imagine a complete entity from the point of view of its component parts giving out force and safety. The notion of robustness is associated with a lot of activity domains. 
ROMANIAN JOURNAL

OF TRANSPORT INFRASTRUCTURE

Carmen Bucur

Checking the low track lattice girder bridges for robustness

Consequently, there are many definitions individualizing the robustness notion depending on the study domain. Same examples are in Table 1.

Table 1. Domain and robustness corresponding definition

\begin{tabular}{|l|l|}
\hline Control Theory & $\begin{array}{l}\text { The degree to which a system is insensitive to effects that are not } \\
\text { considered in the design, [SLOTINE \& LI, 1991]. }\end{array}$ \\
\hline $\begin{array}{l}\text { Design } \\
\text { Optimization }\end{array}$ & $\begin{array}{l}\text { A robust solution in an optimization problem is one that has the best } \\
\text { performance under its worst case (max-min rule), [KOUVELIS \& YU, } \\
\text { 1997]. }\end{array}$ \\
\hline Language & $\begin{array}{l}\text { The robustness of language...is a measure of the ability of human } \\
\text { speakers to communicate despite incomplete information, ambiguity, } \\
\text { and the constant element of surprise, [BRISCOE, 1997]. }\end{array}$ \\
\hline $\begin{array}{l}\text { Product } \\
\text { Development } \\
\text { and Quality } \\
\text { Control }\end{array}$ & $\begin{array}{l}\text { The measure of the capacity of a production process to remain } \\
\text { unaffected by small but deliberate variations of internal parameters so as } \\
\text { to provide an indication of the reliability during normal use. }\end{array}$ \\
\hline $\begin{array}{l}\text { Software } \\
\text { Engineering }\end{array}$ & $\begin{array}{l}\text { The ability...to react appropriately to abnormal circumstances (i.e., } \\
\text { circumstances "outside of specifications"). A system may be correct } \\
\text { without being robust, [MEYER, 1997]. }\end{array}$ \\
\hline $\begin{array}{l}\text { Structural } \\
\text { Standards }\end{array}$ & $\begin{array}{l}\text { Robustness, the ability of a structure to withstand events like fire, } \\
\text { explosions, impact or the consequences of human error, without being } \\
\text { damaged to an extent disproportionate to the original cause", [Eurocode } \\
\text { EN 1991-1-7:2006 (1.5.14)]. }\end{array}$ \\
\hline
\end{tabular}

Nowadays, there are some groups of specialists intensely studying this subject and who also organize events dedicated to it. However, there is no mutual consensus of ideas neither in approaching this phenomenon nor regarding the used terminology and the dealing with it.

In the domain literature there are presented three moments that significantly stimulated these studies. The starting event raising the interest in this domain is the gas explosion at Ronan Point building, London, in 1968. Here are some events that gave an impulse to the research in this field; they were the terrorist attacks at Alfred Murrah Building, Oklahoma and at the Khobar towers in Saudi Arabia. The third important moment was the terrorist attack on the $11^{\text {th }}$ September in the United States of America. Each event had a social, economic and emotional impact, which had individualized it. There are multiple causes of the collapses: natural phenomena, designing or building mistakes, improper use, etc. Lately the terrorism also appeared.

This paper intends to add to the existing studies a new research in the field domain. The study object is focused on three steel lattice girder low track railway structures. 
ROMANIAN JOURNAL

OF TRANSPORT INFRASTRUCTURE

Carmen Bucur

Checking the low track lattice girder bridges for robustness

The article also contains a short description of the way the structural robustness concept is found in the national codes.

\section{MODALITY THE ROBUSTNESS CHECKING IS APROCHED, STRUCTURAL ROBUSTNESS CONCEPT IN THE NATIONAL CODES}

The present day way of carrying out the robustness study for a structure is to propose some scenarios where (from various causes) some structural elements are removed. They aim to find out some technical solutions for the structure to have ways to redistribute the efforts and be able to remain operational for the period immediately after the elements removal. This approach is required by the society, which, when spending resources expects the engineers to design constructions able to remain operational even under special circumstances.

And then who is to comply better with this requirement, the bull which, at a certain moment remains without a leg, or the millipede, under the same circumstances?

The modern technical designing codes are based on the reliability theory so they consider they are based on a safely mathematical substantiated [FABER\& NARASIMHAN, 2011].

Yet these methods fail regarding the identification and adequate treatment of the disproportionate collapse potential. There are three motives for this failure. First, the design equations are defined and applied only at the local level (checking the forces in the cross section or the element stability). Consequently the structural stability is also taken into consideration only to the local level. Secondly, the events of low probability and the unforeseen ones are not taken into consideration. This simplification is not accepted for the non-robust structures where the low probability of the local collapse may lead to a great probability of a global collapse. Thirdly, the probabilistic fundamental concept requires an admissible probability to be established for collapse. Having in view the important losses that may result from a disproportionate collapse, it is difficult to reach a consensus on the numerical value of the admissible probability of such a failure. A quality design implies the taking into consideration tolerances higher than the minimum designing requirements imposed by a norm or a code. The existence and the possible consequences of the abnormal loads, as well as the possibility of a disproportionate collapse should be explicitly taken into consideration in the codes and standards, becoming an integrant part of the designing process. The norms should highlight the fact that the risk management of the disproportionate collapse shall be a 
ROMANIAN JOURNAL

OF TRANSPORT INFRASTRUCTURE

necessary requirement for the design, no matter if the starting event is an „accidental” or „normal” load or if they affect the general structural stability. In the same time, the involved team - owner, architect, designer, constructor shall recognize the fact that the risk is inevitable, that the disproportionate collapse risk cannot be totally eliminated, yet being possible to be managed. A compromise shall be made between the risk diminishing, additional cost and the building safety degree. The designer shall inform the owner on what can be obtained from a quality design, as well as on the uncertainty that may appear in the achievement of the performance targets.

They propose limit values for a damage, which, starting from one single affected element - shall remain a local damage. Comparing some more technical regulations in force [GSA 2003, COST Action TU0601 2007-2009, Arup 2011] one can say - with some variations - that the damage may be considered a local one, if: 1) where its development can be vertical, its extension is from the level the abnormal event appears to the next upper and lower ones; 2) where its development can be horizontal: (a) for the outer areas, about 15-20\% from the floor surface for at most two bays; (b) for the indoor areas, about $30 \%$ from the total floor area, at most in the bays adjacent the destroyed element.

In Romania, the Euro-codes are in force together with National Annexes. They contain a lot of stipulations aiming to increase the structural robustness and to limit any possibility of a local collapse [BUCUR et all 2014, SANTOS et all 2013].

In SR-EN 1990:2004 [EN 1990:2002] - Basis of Structural Design:

(i) Section $2-2.1$ (4) is stipulated: "A structure shall be designed and executed in such a way that it will not be damaged by events like explosion, impact and the consequences of human errors, to an extent disproportionate to the original cause. In the case of fire, the structural resistance shall be adequate for the required period of time."

(ii) Practically, in Section $2-2.1$ (5)P it is also presented the way the structural robustness shall be checked. Thus: „P Potential damage shall be avoided or limited by appropriate choice of one or more of the following: avoiding, eliminating or reducing the hazards to which the structure can be subjected; selecting a structural form which has low sensitivity to the hazards considered; selecting a structural form and design that can survive adequately the accidental removal of an individual member or a limited part of the structure, or the occurrence of acceptable localized damage; avoiding as far as possible structural 
ROMANIAN JOURNAL

OF TRANSPORT INFRASTRUCTURE

systems that can collapse without warning; tying the structural members together."

(iii) Section 2.2.(5) letter (e): „, other measures relating to the following other design matters: the basic requirements; the degree of robustness (structural integrity); durability, including the choice of the design working life; the extent and quality of preliminary investigations of soils and possible environmental influences; the accuracy of the mechanical models used; the detailing."

The practical designing measures required to attain this aim are mainly provided in SR-EN 1991-1-7:2007 [EN 1991-1-7:2006] Euro-code 1: Part 1-7 General Actions - Accidental Actions.

(i) Section 1 paragraph 1.5.14 where the robustness notion is defined (see table 1);

(ii) Section 3 paragraph 1. (2) where the designing strategies for accidental situations are defined (figure 3.1 - in code). In figure 1 is presented the scheme in the code.

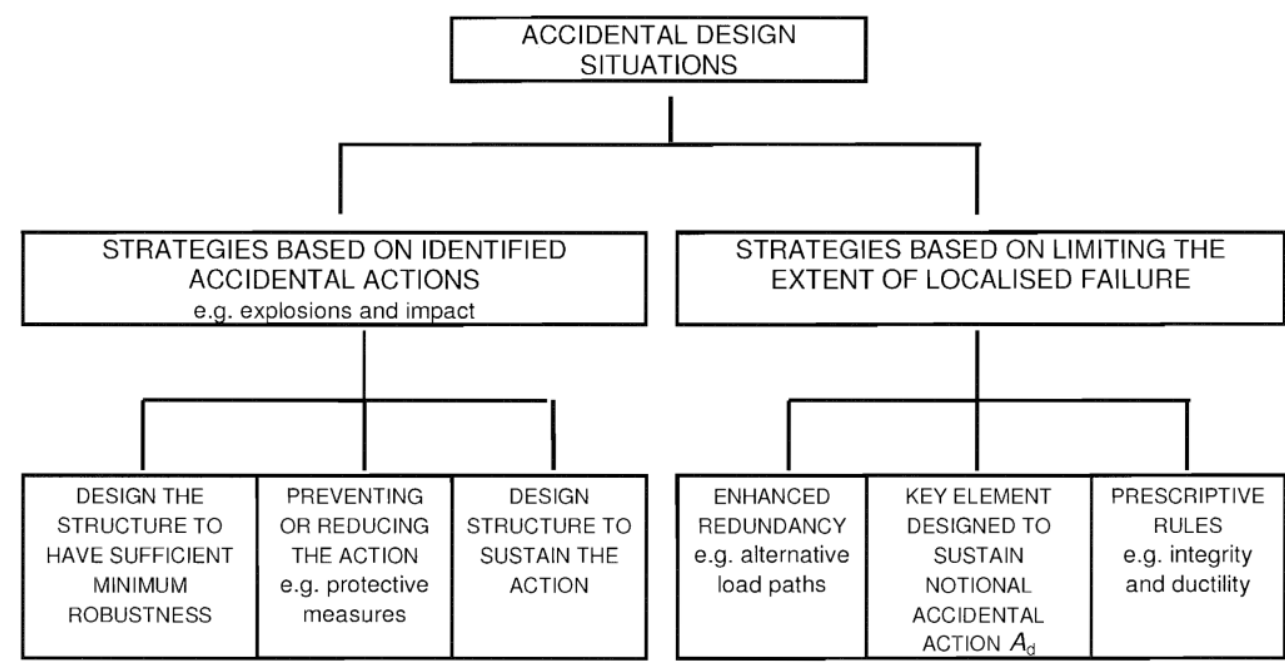

Figure 3.1 - Strategies for Accidental Design Situations

Figure 1. The scheme in the SR-EN 1991-1-7:2007 [EN 1991-1-7:2006], code section 3 [14]

In note 3 is presented: "Strategies based on unidentified accidental actions cover a wide range of possible events and are related to strategies based on limiting the extent of localized failure. The adoption of strategies for limiting the extent of 
ROMANIAN JOURNAL

OF TRANSPORT INFRASTRUCTURE

localized failure may provide adequate robustness against those accidental actions, or any other action resulting from an unspecified cause".

In the cases some other technical regulations exist, they are in line with the Euro-codes. Thus, for the seismic action design they have drawn up the Seismic Design Code, Part 1 - P100-1/2013, Earthquake Resistant Design of Buildings. In the paragraphs 4.4.1.1 and 4.4.1.2 concepts like the following can be found: (1) The structural simplicity implies the existence of continuous and strong enough structural system able to ensure a clear path, as direct as possible, non-interrupted for the seismic forces, irrespective their direction, up to the founding ground. The seismic forces that appear in all the elements of a building, as mass forces, are taken over by the floors - horizontal diaphragms and sent to the vertical structure, and from this they are transferred to the foundations and to the ground. The design shall ensure that no discontinuities will appear along this path. For instance, a large hole in the floor or the absence, from the floor, of the reinforcing bars collecting the inertia forces to send them to the vertical structure - also represent discontinuities. (2) The seismic design aims to provide the structure of the building with the appropriate redundancy. This will ensure that: (i) the failing of one single element or of one single structural tie do not expose the structure to the loss of its stability; (ii) a plasticized mechanism is obtained with sufficient plastic zones, able to allow the exploitation of the resistance reserves of the structure and an advantageous dissipation of the seismic energy. These measures aim to increase the structural robustness.

\section{CASE STUDIES}

The lattice girder for the low track bridge is object of the case studies. The structures, three in number, (Figure 2), low track railway bridges, without upper wind-bracings, namely:

1. Lattice girder with parallel flanges, $21.0 \mathrm{~m}$ span (GZ21_straight);

2. Lattice girder with parallel flanges, $21.0 \mathrm{~m}$ span, with $30^{\circ}$ obliquity (GZ21_skew);

3. Lattice girder with parallel flanges, $48.0 \mathrm{~m}$ span (GZ48_ straight), [BUCUR, 2013]. 
ROMANIAN JOURNAL

OF TRANSPORT INFRASTRUCTURE

Carmen Bucur

Checking the low track lattice girder bridges for robustness

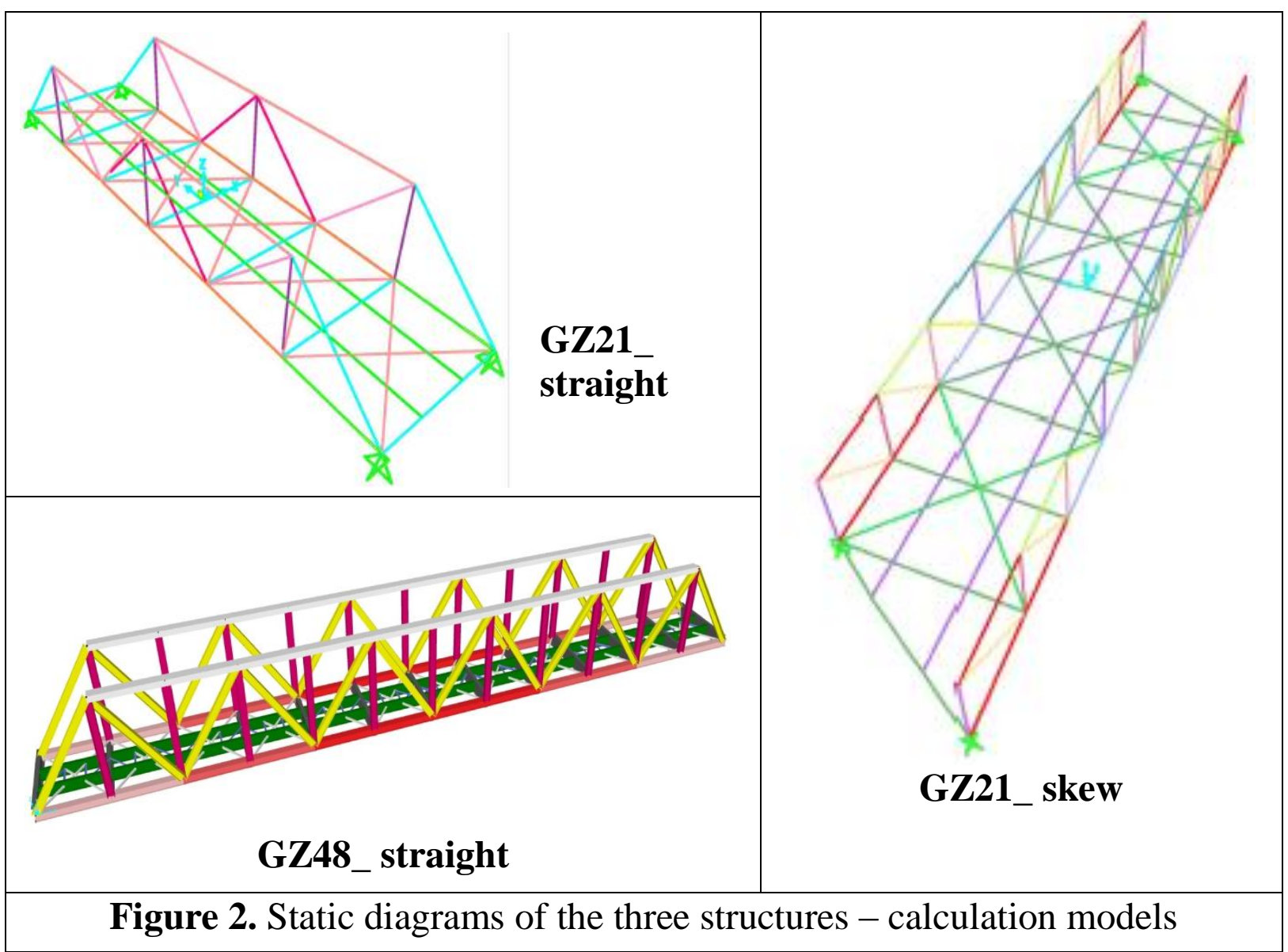

Structural response will be presented by means of displacements and its own dynamic characteristics for the following scenarios:

a) Elimination of a bar in the low flange in the girder central area - marked C1;

b) Elimination of a bar in the upper flange in the girder central area marked C2;

c) Elimination of bracings in the low flange in a panel in the girder centre - marked C3;

The structure initial configuration is marked $\mathbf{C 0}$.

The structural response is only for the dead load.

Examples with these scenarios are presented in figure 3. 
ROMANIAN JOURNAL

OF TRANSPORT INFRASTRUCTURE

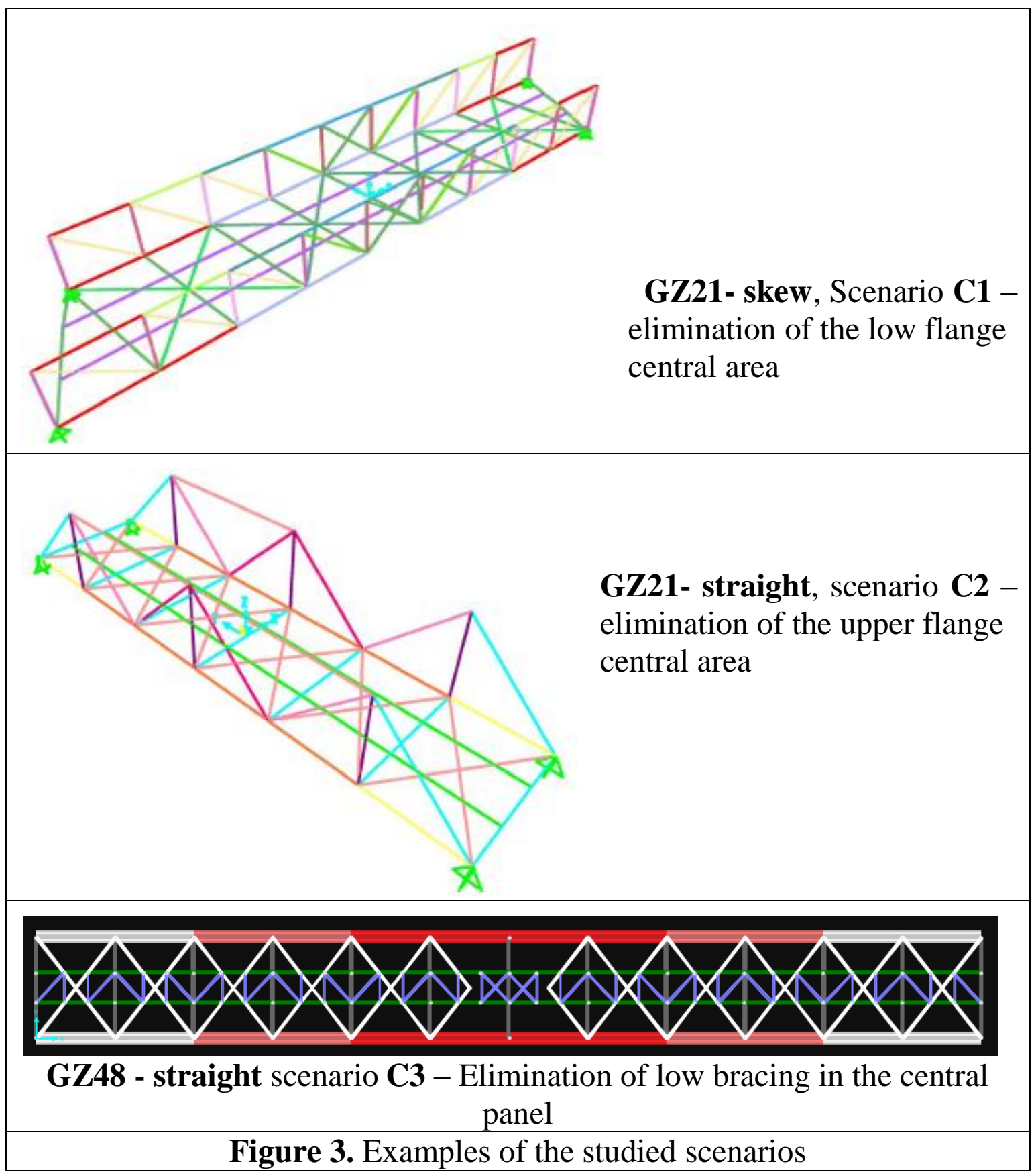

\subsection{Comments regarding the deflection in the center of the structure}

In table 1 there are presented the deflections for the four scenarios as well as the type ratios $\frac{{\text { deflection } C_{i}}_{i}}{{\text { deflection } C_{0}}_{0}}$. 
ROMANIAN JOURNAL

OF TRANSPORT INFRASTRUCTURE

Table 1. Deflections in the structure center $(\mathrm{mm}) / /$ Ratio: deflection Ci /deflection CO

\begin{tabular}{|c|c|c|c|c|c|c|c|}
\hline Type & C0 & \multicolumn{2}{|c|}{ C1-inf / ratio } & \multicolumn{2}{c|}{ C2-sup / ratio } & \multicolumn{2}{c|}{$\begin{array}{c}\text { C3-contrav // } \\
\text { ratio }\end{array}$} \\
\hline GZ21_straight & -1.30 & -2.20 & 1.69 & -38.00 & 29.23 & -1.30 & 1.00 \\
\hline GZ21_skew & -4.50 & -5.90 & 1.31 & -9.90 & 2.20 & -4.50 & 1.00 \\
\hline GZ48_straight & -9.42 & -11.43 & 1.21 & -256.77 & 27.26 & -9.37 & 0.99 \\
\hline
\end{tabular}

One can find out that the elimination of an element from the low flange brings about 1.20 and 1.70 times increase of the deflection. The elimination of an element from the low bracing, as it was expected for such a type of load, has no effect. On the other hand, removing of an element from the upper girder in the middle of the bridge brings about an increase of almost 30 times at the straight structures. For a skew structure the increase is about 2 times.

In conclusion we can see that the straight structures are very sensitive to the elimination of an element from the upper girder. The skew structure has a more stable behaviour.

\subsection{Comments regarding the own dynamic characteristics}

\section{Fundamental period}

In table 2 the periods of the fundamental vibration mode are presented for the four scenarios as well as the type ratios $\frac{\text { fundamental period } C_{i}}{\text { fundamental period } C_{0}}$.

Table 2. Periods of the fundamental mode (sec) //

Ratio $\mathbf{T}_{\text {fundamental Ci }} / \mathbf{T}_{\text {fundamental }} \mathbf{C}$

\begin{tabular}{|c|c|c|c|c|c|c|c|}
\hline Type & Co & \multicolumn{2}{|c|}{$\begin{array}{c}\text { C1-inf // } \\
\text { ratio }\end{array}$} & \multicolumn{2}{c|}{ C2-sup // ratio } & \multicolumn{2}{c|}{$\begin{array}{c}\text { C3-contrav // } \\
\text { ratio }\end{array}$} \\
\hline GZ21_straight & 0.2762 & 0.2828 & 1.02 & 0.6296 & 2.28 & 0.2792 & 1.01 \\
\hline GZ21_skew & 0.1352 & 0.1550 & 1.15 & 0.1832 & 1.36 & 0.1381 & 1.02 \\
\hline GZ48_straight & 0.5388 & 0.5602 & 1.04 & 1.2154 & 2.26 & 0.5437 & 1.01 \\
\hline
\end{tabular}

The first observations may be made concerning the dynamic behaviour for the entire structures. The $21.0 \mathrm{~m}$ long structures are classified among those having rigid behaviour. The $48.0 \mathrm{~m}$ long structure is situated at the upper limit of the rigid behaviour. It is to be noted that ratio of values of their periods. The lowest value of the fundamental period is that of a $21.0 \mathrm{~m}$ long skew structure. 
ROMANIAN JOURNAL

OF TRANSPORT INFRASTRUCTURE

The straight structure of the same span has its fundamental period two times higher. The $48.0 \mathrm{~m}$ long straight structure (that is 2 times longer) has the value of the fundamental period two times higher than the $21.0 \mathrm{~m}$ long straight structure, and four times higher than the $21.0 \mathrm{~m}$ long skew structure.

The removing of an element from the low girder or from the low bracing brings - in central area - about no effect on the value of the fundamental period. The removing of the upper flange in the central panel remains the scenario that produces the maximum effect for this mechanical characteristic too. So, the skew girder still behaves the best, the increase of the period value being of about $40 \%$. For the straight structures the increase is of about $130 \%$. On the other hand, the ratio of the periods values of the $21.0 \mathrm{~m}$ long straight girder $/ 21.0 \mathrm{~m}$ long skew girder increases to 3.5 whereas the ratio of the periods values for the straight girders $(48.0 \mathrm{~m}$ long straight girder / $21.0 \mathrm{~m}$ long straight girder) remains at the value 2 .

\section{Shape of the fundamental vector}

In table 3 the shapes of the fundamental vectors are presented for the fundamental vibration mode corresponding to the four scenarios.

Table 3. Form of the specific vector of the fundamental vibration mode

\begin{tabular}{|c|c|c|c|c|}
\hline Type & $\mathrm{CO}$ & C1-inf & C2-sup & C3-contrav \\
\hline $\begin{array}{l}\text { GZ21_- } \\
\text { straight }\end{array}$ & $\begin{array}{c}\text { Lateral vibration } \\
\text { of the upper } \\
\text { flange }\end{array}$ & $\begin{array}{l}\text { The same as for } \\
\text { scenario C0 }\end{array}$ & $\begin{array}{l}\text { Rotation round } \\
\text { longitudinal axis } \\
\text { placed in the plan } \\
\text { of the whole } \\
\text { girder }\end{array}$ & $\begin{array}{l}\text { The same as for } \\
\text { scenario C0 }\end{array}$ \\
\hline $\begin{array}{c}\text { GZ21_- } \\
\text { skew }\end{array}$ & $\begin{array}{l}\text { Rotation round } \\
\text { the longitudinal } \\
\text { axis }\end{array}$ & $\begin{array}{l}\text { Rotation round } \\
\text { longitudinal axis } \\
\text { placed in the plan } \\
\text { of the whole } \\
\text { girder }\end{array}$ & $\begin{array}{l}\text { The same as for } \\
\text { scenario } C 1 \text {-inf }\end{array}$ & $\begin{array}{c}\text { The same as for } \\
\text { scenario } \mathrm{C} 0\end{array}$ \\
\hline $\begin{array}{c}\text { GZ48_- } \\
\text { straight }\end{array}$ & $\begin{array}{c}\text { Lateral vibration } \\
\text { of the upper } \\
\text { flange }\end{array}$ & $\begin{array}{l}\text { The same as for } \\
\text { scenario } \mathrm{C} 0\end{array}$ & $\begin{array}{l}\text { The same as for } \\
\text { structure } \\
\text { GZ21 straight }\end{array}$ & $\begin{array}{c}\text { The same as for } \\
\text { scenario C0 }\end{array}$ \\
\hline
\end{tabular}

The fundamental vector of the $21.0 \mathrm{~m}$ long skew girder is a rotation round a longitudinal axis. This shape of the vector remains the same for all the scenarios - the axis being either in the center of the structure or in the plan of the whole girder. 
ROMANIAN JOURNAL

OF TRANSPORT INFRASTRUCTURE

The elimination of the wind bracing element does not bring about changes of the shape of the fundamental vector.

If one structural element is removed from the low or upper flange, the vector shape is that of the rotation round a longitudinal axis placed in the plane of the girder which remained undamaged for all types of structures.

So, we can see that the disturbing element for the straight structures is the upper flange.

\section{CONCLUSIONS}

The robustness is associated to a complete entity by point of view of the elements assumed to be part of it, granting it force and safety. The notion is used in a lot of everyday life domains so that specific definitions are enunciated.

From the present day domain literature it results that, as far as we refer to the adequate identification and dealing with of the potential for a disproportionate collapse, the used methods in the modern designing technical regulations fail. The examples given for the loss of the structural integrity are many and lead to this conclusion.

From the presented case studies we can find out that without being fundamentally different in point of configuration, each structure behaves differently in the proposed scenarios. In the same time conclusions can be drawn regarding the higher or less degree of influence of some types of removed elements. For the studied structures - low track lattice girders bridges, without upper wind-bracings - the element endangering the structural robustness is the upper flange.

\section{REFERENCES}

[1]. BRISCOE T. - Robust Parsing - Survey of the State of the Art in Human Language Technology, G.B. Varile and A. Zampolli, Editors., Cambridge University Press: Cambridge; New York; Pisa, Italy. 513p. 1997

[2]. BUCUR C., BUCUR V.M., ZANAICA L., SANTOS S.H.C. - Comment on European Codes and Comparison of Brazilian, Italian, Romanian Codes Concerning the Approach of Robustness - Engenharia Estudo e Pesquisa, ABPE (Asoc. Braziliană de Poduri și Structuri - filială IABSE), v.14, nr.2, pp. 27-45jul./dez. 2014, ISSN 2316-591X; www.revistaeep.com, 2014

[3] BUCUR C., DERZSI S. - Scenarios for Robustness evaluations of a Bridge type structure - Lattice girder, parallel flanges, low track - International multidisciplinary scientific geoconferences, SGEM-2014, Bulgaria - Conference Proceedings, Vol. III, 
ROMANIAN JOURNAL

OF TRANSPORT INFRASTRUCTURE

Carmen Bucur

Checking the low track lattice girder bridges for robustness

pp.369-376 > ISSN 1314-2704; ISBN 978-619-7105-19-3; $\quad$ DOI 10.5593/sgem2014B53, 2014

[4] FABER M., NARASIMHAN H. - COST Action TU0601 - Robustness of Structures : A summary, 2011

[5] KOUVELIS P., YU G. -, Robust Discrete Optimization and Its Applications. Nonconvex Optimization and Its Applications; V14. Kluwer Academic Publishers: Dordrecht, Boston, 356 p. 1997

[6] MEYER B. - Object-Oriented Software Construction - $2^{\text {nd }}$ edn. Prentice Hall PTR, 1254 p. 1997

[7] SANTOS S.H., ZANAICA L., BUCUR C., LIMA S.S., ARAI A. - Comparative study of Codes for the Seismic design of Structures - Mathematical Modelling in Civil Engineering, Vol. 9 - No. 1-2013, pp 1-15, DOI: 10.2478/mmce-2013-0001 http://versita.com, and http://mmce.rs.utcb.ro/, 2013

[8] SLOTINE JJE, LI W. - Applied Nonlinear Control - Prentice Hall: Englewood Cliffs, N.J., 459 p. 1991

[9] *** COST Action TU0601 \& E55 pp. 91-102, ISSN 978-3-909386-29-1, Switzerland/2010; and the site http://www.cost-tu0601.ethz.ch/, 2009

[10] *** GSA - Progressive Collapse Analysis and Design Guidelines for New Federal Office Buildings and Major Modernization Projects - June 2003

[11] *** Review of international research on structural robustness and disproportionate collapse - Communities and Local Government, Centre of the Protection of National Infrastructure - Arup 2011

[12] *** Cod de proiectare seismică, Partea 1 - P100-1/2013, Prevederi de proiectare pentru clădiri, 2013 [Seismic Design Code P100-1/2013 - Design Provisions for Buildings]

[13] $\quad * * *$ SR-EN 1990:2004 - Bazele proiectării structurilor

[14] *** SR-EN 1991-1-7:2007 Euro-code 1: Partea 1-7 Acțiuni generale - Acțiuni Accidentale [EN 1991-1-7:2006 Euro-code 1 - Actions on Structures - Part 1-7: General Actions - Accidental Actions. London: British Standards Institution] 